\title{
Microwave-Assisted Acid Hydrolysis of Proteins Combined with Liquid Chromatography MALDI MS/MS for Protein Identification
}

\author{
Hongying Zhong, Sandra L. Marcus, and Liang Li \\ Department of Chemistry, University of Alberta, Edmonton, Alberta, Canada
}

\begin{abstract}
Simple and efficient digestion of proteins, particularly hydrophobic membrane proteins, is of significance for comprehensive proteome analysis using the bottom-up approach. We report a microwave-assisted acid hydrolysis (MAAH) method for rapid protein degradation for peptide mass mapping and tandem mass spectrometric analysis of peptides for protein identification. It uses $25 \%$ trifluoroacetic acid (TFA) aqueous solution to dissolve or suspend proteins, followed by microwave irradiation for $10 \mathrm{~min}$. This detergent-free method generates peptide mixtures that can be directly analyzed by liquid chromatography (LC) matrix-assisted laser desorption ionization (MALDI) mass spectrometry (MS) without the need of extensive sample cleanup. LC-MALDI MS/MS analysis of the hydrolysate from $5 \mu \mathrm{g}$ of a model transmembrane protein, bacteriorhodopsin, resulted in almost complete sequence coverage by the peptides detected, including the identification of two posttranslational modification sites. Cleavage of peptide bonds inside all seven transmembrane domains took place, generating peptides of sizes amenable to MS/MS to determine possible sequence errors or modifications within these domains. Cleavage specificity, such as glycine residue cleavage, was observed. Terminal peptides were found to be present in relatively high abundance in the hydrolysate, particularly when low concentrations of proteins were used for MAAH. It was shown that these peptides could still be detected from MAAH of bacteriorhodopsin at a protein concentration of $1 \mathrm{ng} / \mu \mathrm{lor} 37 \mathrm{fmol} / \mu \mathrm{l}$. To evaluate the general applicability of this method, it was applied to identify proteins from a membrane protein enriched fraction of cell lysates of human breast cancer cell line MCF7. With one-dimensional LC-MALDI MS/MS, a total of 119 proteins, including 41 membrane-associated or membrane proteins containing one to 12 transmembrane domains, were identified by MS/MS database searching based on matches of at least two peptides to a protein. (J Am Soc Mass Spectrom 2005, 16, 471-481) @ 2005 American Society for Mass Spectrometry
\end{abstract}

$\mathrm{E}$ fficient protein degradation or digestion holds the key for the success of the bottom-up proteome analysis approach of using mass spectrometry (MS) for protein identification. This is particularly true in the case of analyzing membrane proteins. Membrane proteins play an important role in many biological processes. However, the intrinsic difficulty of solubilization makes them difficult to be analyzed by proteomic methods developed for soluble proteins [1, 2]. Insoluble membrane protein aggregates cannot be readily degraded by proteases. Therefore, buffers containing concentrated urea, detergents, and other salts are often chosen for membrane protein solubilization. In addition to the interference encountered with mass spectrometric detection, concentrated urea or detergents denature many proteases and decrease their ac-

Published online February 10, 2005

Address reprint requests to Dr. L. Li, Department of Chemistry, University of Alberta, E3-44 Chemistry Building, Edmonton, Alberta T6G 2G2, Canada. E-mail: liang.li@ualberta.ca tivity to cleave proteins. There are a number of reports describing technical advances to enable membrane protein analysis using the shotgun proteomics approach in which proteins are dissolved in a buffer containing surfactants or in an organic solvent, followed by protein digestion and liquid chromatography (LC) tandem mass spectrometry (MS/MS) analysis of the peptides [3-12]. Protein digestion was done with trypsin [3-7], cyanogen bromide $(\mathrm{CNBr})$-mediated enzymatic digestion [8-11], and nonspecific proteinase $\mathrm{K}$ [12].

Recently, acid-catalyzed hydrolysis has been developed as an alternative technique to degrade the proteins into small peptides for MS analysis. The analytical application of acid hydrolysis for generating peptides can be dated back to the classic protein sequencing work of Sanger and Thompson [13]. Prior to the use of MS as a major tool for protein identification, limited acid hydrolysis had been used as a means of generating peptides from proteins separated by SDS-PAGE for peptide mapping and Edman microsequencing [14, 15]. 
With recent advances in MS for proteome analysis, several groups have explored the use of limited acid hydrolysis to generate peptides for peptide mass mapping or tandem MS analysis [16-24]. A variety of experimental conditions, including the use of acids of different strengths, organic and inorganic acids, and liquid and vapor phases have been studied for optimal degradation of proteins in solution, in gel, or surfacebound. For example, Li, (Anqun) et al. demonstrated that using formic acid, cleavage at aspartyl residues of proteins was efficient and specific for both soluble and insoluble proteins [21]. Shevchenko et al. reported the use of $6 \mathrm{M} \mathrm{HCl}$ for in-gel digestion of bacteriorhodopsin (BR) [22] and demonstrated that acid hydrolysis was superior to that of trypsin digestion for handling this very hydrophobic membrane protein. MALDI hybrid quadrupole time-of-flight (Qq-TOF) mass spectrometry was used to generate product ion spectra of peptides extracted from the in-gel acid hydrolysis method.

In this work, we report a method of protein identification based on microwave-assisted acid hydrolysis (MAAH) using trifluoroacetic acid (TFA) for protein degradation, followed by LC-MALDI MS/MS of the resultant peptides. The use of microwave irradiation to accelerate chemical or enzymatic reactions has been extensively explored. The first demonstration of microwave-assisted organic synthesis was made independently in the research laboratories of Giguere [25] and Gedye [26]. Since then, microwave irradiation has been used to assist in various chemical reactions [27, 28]. There were reports of using microwave irradiation for the hydrolysis of peptides and proteins. Wang and co-workers demonstrated the use of microwave irradiation to accelerate protein hydrolysis to form amino acids [29, 30]. Microwave ovens have now been used extensively for protein hydrolysis to generate amino acids for amino acid composition analysis [28]. Selective hydrolysis of aspartyl peptide bond of peptides has been studied [31]. Enhancement of alcalase-catalysis reaction rate by microwave irradiation has been demonstrated [32]. More recently, Pramanik and co-workers have illustrated the use of microwave to enhance Akabori reaction for peptide analysis $[33,34]$ and to accelerate proteolytic cleavage of proteins for peptide mass mapping by MALDI MS and ESI LC/MS [35].

Herein, the analytical performance of the MAAH method is demonstrated in two areas of current proteomics applications: one for detailed characterization of an isolated protein and another for mapping of a subset of proteome. Using the integral membrane protein, BR, as a model system, we illustrate that MAAH can be used to generate a number of overlapped peptides with high protein sequence coverage, which allows for detailed analysis of protein sequences and chemical modifications. The application of this method for proteome analysis is illustrated in the analysis of membrane proteins isolated from human breast cancer cell line by LC-MALDI MS/MS with a heated droplet interface [36].

\section{Experimental}

\section{Materials and Reagents}

Unless otherwise noted, all chemicals were purchased from Sigma (St. Louis, MO) and were of analytical grade. For HPLC separation, MS analysis, and preparation of digestions, HPLC grade water, methanol, and acetonitrile were used (Fisher Scientific, Mississauga, ON). 37\% $\mathrm{HCl}$ (ACS grade) was from Merck KGaA, Darmstadt, Germany. Human breast cancer cell line, MCF7 cells (ATCC HTB-22), was purchased from the American Type Culture Collection (Manassas, VA).

\section{Membrane Protein Fractionation}

MCF7 cells were grown in $15 \mathrm{~cm}$ diameter plates in ATCC medium at $37^{\circ} \mathrm{C}$ for 2 weeks. The growth medium was aspirated to leave a monolayer of cells on the plates, which were then placed on an ice-cold metal tray. The plates were washed three times with ice-cold $10 \mathrm{ml} \mathrm{PBS}^{++}$buffer $\left(0.9 \mathrm{mM} \mathrm{CaCl}, 0.5 \mathrm{mM} \mathrm{MgCl}_{2}\right.$, $0.7 \mathrm{mM} \mathrm{KH}_{2} \mathrm{PO}_{4}, 8 \mathrm{mM} \mathrm{NaHPO}, 1 \mathrm{mM} \mathrm{KCl}$, and $0.1 \mathrm{M}$ $\mathrm{NaCl}$ ) and then $2.5 \mathrm{ml}$ saponin lysis buffer $[0.2 \%$ saponin in $50 \mathrm{mM}$ Tris- $\mathrm{HCl} \mathrm{pH} 7.5$ with $1 \mathrm{mM}$ phenylmethylsulfonyl fluoride (PMSF)] was added to each dish. Following incubation on ice for 5 min with constant rocking, the cells were scraped from the plates and collected with the buffer solution. The suspension was centrifuged at $17,400 \mathrm{~g}$ for $15 \mathrm{~min}$ at $4{ }^{\circ} \mathrm{C}$. The supernatant contained cytosolic proteins. The cell pellets were washed by resuspending in a total volume of $10 \mathrm{ml}$ wash buffer (50 mM Tris- $\mathrm{HCl}$ pH 7.5 with $1 \mathrm{mM}$ PMSF). The pellets were combined into one centrifuge tube and centrifuged at $17,400 \mathrm{~g}$ for $15 \mathrm{~min}$ at $4{ }^{\circ} \mathrm{C}$. The pellet was resuspended in $12 \mathrm{ml}$ Triton $\mathrm{X}-100$ buffer (1\% Triton $\mathrm{X}-100$ in $50 \mathrm{mM}$ Tris- $\mathrm{HCl} \mathrm{pH} 7.5$ with $1 \mathrm{mM}$ PMSF) and incubated on ice for $15 \mathrm{~min}$ with vortexing at $5 \mathrm{~min}$ intervals to release membrane proteins. The preparation was then centrifuged (as above) to remove insoluble materials. Dithiothreitol (DTT) was added to the supernatant to a final concentration of $20 \mathrm{mM}$. The solution was incubated for $1 \mathrm{~h}$ at $37^{\circ} \mathrm{C}$. Iodoacetamide was added to a final concentration of $20 \mathrm{mM}$ and the solution was left to stand for $1 \mathrm{~h}$ at room temperature in the dark. All disulfide linkages should have been reduced and carbamidomethylated. The supernatant was then mixed with three volumes of cold acetone $\left(-20^{\circ} \mathrm{C}\right)$ to precipitate the proteins and remove detergents and other chemicals. It was then centrifuged as described above and the protein precipitate was lyophilized and stored at $-70{ }^{\circ} \mathrm{C}$.

\section{Acid Hydrolysis}

In the experiments on method development and evaluation of protein sequence coverage by the peptides generated from BR using acid hydrolysis, a stock solution of BR was prepared by suspending $1 \mathrm{mg}$ of BR in 
$1000 \mu \mathrm{l}$ of an acid such as $25 \%$ TFA with $20 \mathrm{mM}$ DTT added in a $1.5 \mathrm{ml}$ vial. The reason for adding DTT was to avoid oxidization of methionine, tryptophan, and other amino acids. In the analysis of the membrane protein fraction from MCF7 cells, $1 \mathrm{mg}$ of the lyophilized sample was suspended in $100 \mu \mathrm{l}$ of $25 \%$ TFA aqueous solution. In both cases, $10 \mu \mathrm{l}$ of the protein suspension was placed in a $1.5 \mathrm{ml}$ polypropylene centrifuge vial, capped, and sealed with Teflon tape. The vial was placed in a domestic $900 \mathrm{~W}(2450 \mathrm{MHz})$ microwave oven. $100 \mathrm{ml}$ of water in a loosely covered container was placed besides the sample vial to absorb extra microwave energy. The volume of the sample including the acid was limited so that the relatively large sample vial could tolerate the vapor pressure produced when the samples was microwave irradiated. After microwave irradiation for a period indicated in the Results and Discussion, the sample vial was taken from the microwave and the solution was dried in a vacuum centrifuge to remove the acid. The BR digest was resuspended in $100 \mu \mathrm{l}$ of $0.1 \%$ TFA aqueous solution and centrifuged at $16,000 \mathrm{~g}$ for $5 \mathrm{~min}$ to remove any possible residual particles. Fifty $\mu$ l of the solution was injected into the HPLC system for analysis. For the MCF7 digest, the dried sample was resuspended in 100 $\mu l$ of $0.1 \%$ TFA aqueous solution and centrifuged at $16,000 \mathrm{~g}$ for $5 \mathrm{~min}$. $50 \mu \mathrm{l}$ of the solution was injected into the HPLC for analysis.

For the sensitivity and acid hydrolysis efficiency experiments, the $1 \mathrm{mg} / \mathrm{ml}$ stock solution of BR was diluted to various concentrations, from which $10 \mu \mathrm{l}$ samples were irradiated for $10 \mathrm{~min}$.

Care was taken when handling the concentrated acids as well as other precautions that were followed in the use of the microwave oven (see Safety Considerations).

\section{HPLC Separation}

Reversed-phase HPLC separations of the peptides were made using a Vydac C18 column (1 mm i.d. $\times 150 \mathrm{~mm}$; Vydac, Hesperia, CA) on an Agilent 1100 capillary HPLC system. At a flow rate of $50 \mu \mathrm{l} / \mathrm{min}$, a linear gradient from $5 \%$ B to $85 \%$ B over 70 min was used, where mobile phase A was water containing $0.1 \%$ (vol/vol) TFA, and mobile phase B was acetonitrile with $0.1 \%$ (vol/vol) TFA. During the separation period from 10 to $50 \mathrm{~min}$, the eluate was fractionated at $30 \mathrm{~s}$ intervals and deposited directly to the MALDI target (Applied Biosystems, Boston, MA) using the heated droplet ${ }^{\circ}$ interface ${ }^{\circ}[36]$.

\section{MALDI MS and MS/MS}

For peptide mass mapping by MALDI time-of-flight (TOF) MS, a two-layer sample/matrix preparation method $^{\circ}$ was $^{\circ}$ used $^{\circ}[37]^{\circ}$ with $^{\circ} \alpha$-cyano-4-hydroxy-cinnamic acid (HCCA) as matrix. $0.7 \mu \mathrm{l}$ of the first-layer matrix solution containing $12 \mathrm{mg} / \mathrm{ml}$ of HCCA in $20 \%$ methanol/acetone was deposited on the MALDI target and air-dried. $0.5 \mu \mathrm{l}$ of sample was mixed with $0.5 \mu \mathrm{l}$ of matrix (50\% acetonitrile/water saturated with HCCA) and then deposited onto the first layer. The MALDITOF mass spectra were obtained on a Bruker Reflex III time-of-flight mass spectrometer (Bremen/Leipzig, Germany).

For MALDI MS/MS analysis of the HPLC fractions, the peptide samples were prepared using a dried droplet method in which 2,5-dihydroxybenzoic acid (DHB) was used as the matrix. $0.3 \mu \mathrm{l}$ of matrix solution in $50 \%$ acetonitrile/water saturated with DHB was put into each well and then pipetted several times before spotting on the target. Product ion spectra of peptides were obtained in a QSTAR MALDI Qq-TOF mass spectrometer (MDS Sciex, Ontario, Canada).

\section{Data Interpretation and Database Searching}

Database searching using MS/MS spectra was performed by ${ }^{M}$ ASCOT $^{\circ}$ (http:/ / www.matrixscience.com). All the database searching was done against SwissProt using no specification of enzyme type. Methionine oxidization, and deamidation of asparagine and glutamine were set as variable modifications. Carbamidomethylation of cysteine was set as a fixed modification. Potential protein candidates with the highest MOWSE scores were determined from database search. The MS/MS spectra of the matched peptides were examined manually to see if the major peaks observed were matched with the expected fragmentation patterns. If they agreed well, the identification was considered to be positive.

\section{Hydropathy Calculations}

Proteins identified were examined using the ProtParam program $^{\circ}$ available $^{\circ}$ at $^{\circ}$ the $^{\circ}$ EXPASY $^{\circ}$ web $^{\circ}$ site $^{\circ}$ (http: / / us.expasy.org/tools/protparam.html $)^{\circ}$ that $^{\circ}$ allows $^{\circ}$ for calculation of the grand average of hydrophobicity (GRAVY). Positive values are considered as hydrophobic and negative values are considered as hydrophilic.

\section{Safety Considerations}

Procedures and cautions in handling liquid samples for microwave experiments can be found in the literature [28]. ${ }^{\circ}$ Although ${ }^{\circ}$ the $^{\circ}$ sample $^{\circ}$ volume $^{\circ}$ used $^{\circ}$ in $^{\circ}$ this $^{\circ}$ work was generally small $(10 \mu \mathrm{l})$, care was still exercised. The microwave oven was turned off and unplugged from the power after each use. In case of microwave oven malfunction that may result in continued radiation generation even after it is switched off, unplugging from the power should prevent any potential accident from ${ }^{\circ}$ such $^{\circ}$ failure ${ }^{\circ}[28]^{\circ} .^{\circ}$ Care $^{\circ}$ was $^{\circ}$ also ${ }^{\circ}$ taken ${ }^{\circ}$ in ${ }^{\circ}$ handling acids and possible acid vapors during and after microwave hydrolysis. After microwave irradiation of the sample vial it was allowed to cool inside the microwave oven. The cooled sample vial was opened in a wellvented bench area, such as inside a fume-hood. 


\section{Results and Discussion}

\section{Microwave-Assisted Acid Hydrolysis Versus Other Methods}

Figure ${ }^{\circ} 1^{\circ}$ shows ${ }^{\circ}$ the ${ }^{\circ}$ workflow ${ }^{\circ}$ of ${ }^{\circ}$ the ${ }^{\circ}$ proteome $e^{\circ}$ analysis method. Membrane proteins are first extracted from cell lysates using a proper solvent system usually containing surfactants. The sample is then reduced and alkylated, followed by acetone-precipitation. The resulting powder is washed to remove salts, buffers, and soluble proteins. Instead of using surfactants or organic solvents to redissolve the proteins, in our method the protein powder is suspended in an acid such as TFA and then subjected to microwave irradiation. The hydrolysate generated from this microwave-assisted acid hydrolysis (MAAH) process is directly analyzed by LC MS and MS/MS. In this work, LC-MALDI TOF and LC-MALDI Qq-TOF are used for peptide mass mapping and protein identification by MS/MS database searching, respectively.

The ability to hydrolyze proteins from a protein

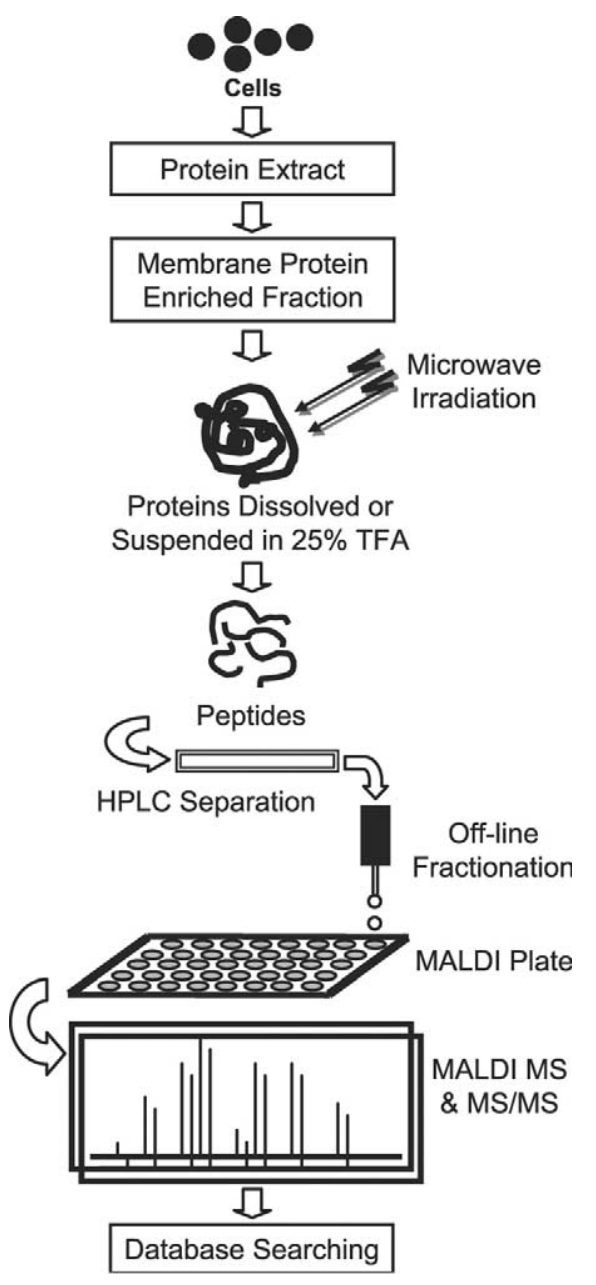

Figure 1. Workflow for the analysis of enriched membrane proteins by microwave-assisted acid hydrolysis for protein degradation, HPLC separation of peptides, and MALDI MS/MS with database search for protein identification. suspension eliminates the need to use strong surfactants, facilitating the downstream mass spectrometric analysis. Strong surfactants are known to cause interferences in MS analysis and must be carefully removed. For ${ }^{\circ}$ xample, in ${ }^{\circ}$ the ${ }^{\circ}$ work ${ }^{\circ}$ of ${ }^{\circ}$ ixson ${ }^{\circ} t^{\circ}{ }^{\circ} .{ }^{\circ}[38],{ }^{\circ} 500^{\circ} \mu$ g of BR was mixed with $10 \mu \mathrm{l}$ of $260 \mathrm{mM}$ SDS for initial solubilization. This was followed by addition of $100 \mu \mathrm{l}$ of buffer containing $7 \mathrm{M}$ urea, $2 \mathrm{M}$ thiourea, $4 \%$ CHAPS, and $5 \mathrm{mM}$ DTT for further solubilization. The dissolved BR was digested by trypsin for LC-ESI MS/MS. However, prior to MS analysis, concentrated urea and SDS had to be removed by an overnight dialysis process. Nevertheless, using this approach they detected an extensive list of peptides that provided complete sequence ${ }^{\circ}$ coverage $^{\circ}$ of $^{\circ} \mathrm{BR}^{\circ}[38]$.

MAAH can significantly increase the speed of protein degradation for proteome analysis using database searching of product ion spectra of peptides. As demonstrated below, MAAH of proteins are generally completed within $10 \mathrm{~min}$, rather than overnight enzymatic digestion. An even longer digestion time is required for enzymatic digestion involving the use of surfactants or organic solvents to solubilize the proteins, attributable to the reduction of enzyme activities. While conventional acid hydrolysis can shorten the protein degradation time, for membrane protein analysis MAAH offers a distinct advantage over other acid hydrolysis methods, i.e., it provides more efficient cleavage inside transmembrane domains. For example, organic acids such as $90 \%$ formic acid have been used for membrane protein solubilization, followed by hydrolysis with or without heating of the protein/acid mixture. Protein hydrolysis using formic acid yields peptides resulting from the preferential cleavage of hydrophilic aspartyl residues, especially the $\mathrm{D}-\mathrm{P}$ bond. The method appears to work well with hydrophilic proteins and some membrane proteins $^{\circ}[21]^{\circ}$ and $^{\circ}$ it $^{\circ}$ is ${ }^{\circ}$ found ${ }^{\circ}$ to $^{\circ}$ be $^{\circ}$ very $^{\circ}$ useful ${ }^{\circ}$ for generating large peptides for mapping posttranslational or chemical modifications of proteins [Zhong and $\mathrm{Li}$, to be submitted]. However, the method provides limited cleavage sites at the hydrophobic transmembrane domains where $\mathrm{D}-\mathrm{P}$ bonds are not expected to be present. In addition, N-terminal formylation of peptides is extensively observed. This is ${ }^{\circ}$ shown ${ }^{\circ}{ }^{\circ}{ }^{\circ}$ Figure $^{\circ} 2 \mathrm{a}^{\circ}$ where ${ }^{\circ} \mathrm{BR}^{\circ}{ }^{\circ}$ as ${ }^{\circ}$ mixed $^{\circ}$ with ${ }^{\circ} 70 \%$ formic ${ }^{\circ}$ acid $^{\circ}[39]^{\circ}$ and $^{\circ}$ heated ${ }^{\circ}$ at ${ }^{\circ} 110^{\circ} \mathrm{C}^{\circ}$ for ${ }^{\circ} 4^{\circ} \mathrm{h} .{ }^{\circ}$ The MALDI spectrum of the hydrolysate (from about 200 ng of BR) displays a number of modified peptides and the overall signal-to-noise ratio of the spectrum is not good. Decreasing the formic acid concentration can decrease the extent of N-terminal formylation, but solubilization of membrane proteins decreases as well, resulting in poor acid cleavage efficiency. For example, no peptide peaks were detected when the mixture of $5 \%$ formic acid and BR, after heating at $110^{\circ} \mathrm{C}$ for $4 \mathrm{~h}$, was analyzed.

MAAH can overcome the solubility problem associated with conventional acid hydrolysis. This is best 

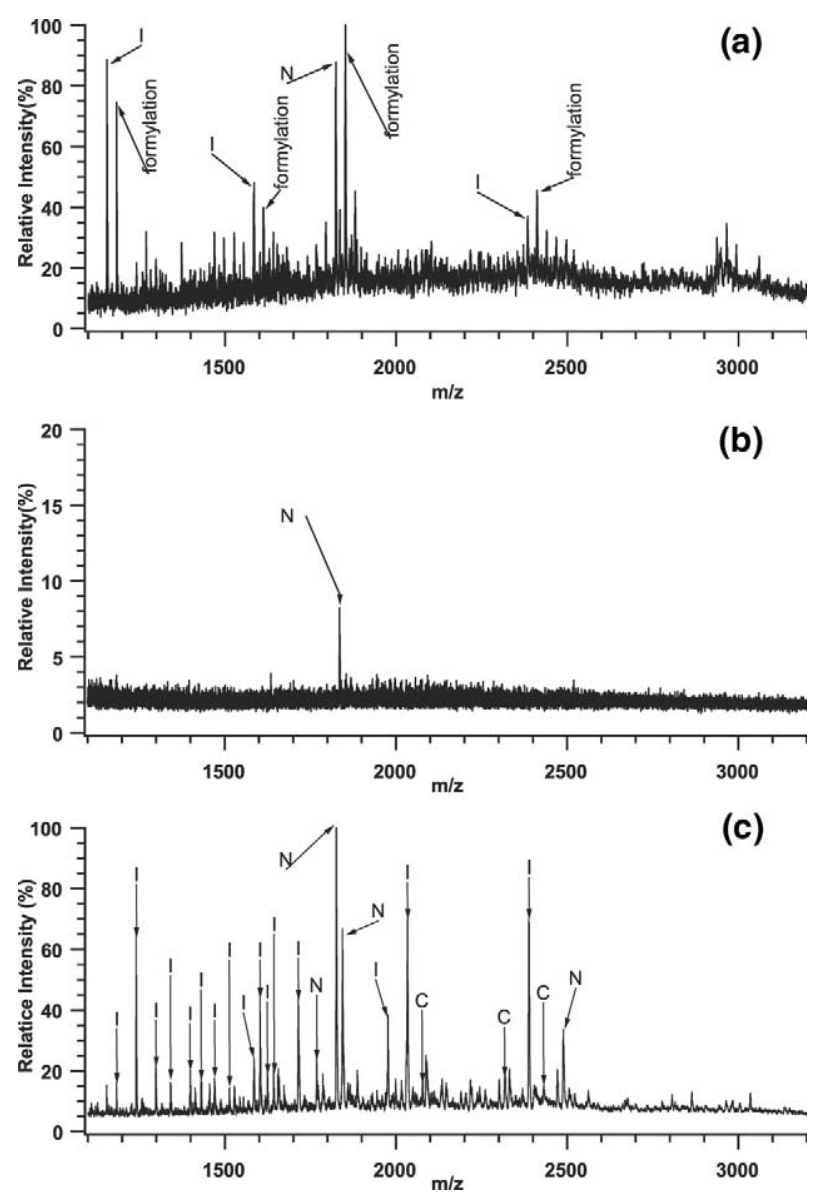

Figure 2. MALDI MS spectra of the peptides generated from the hydrolysis of $200 \mathrm{ng}$ of bacteriorhodopsin under different conditions: (a) $70 \%$ formic acid heated at $110{ }^{\circ} \mathrm{C}$ for $4 \mathrm{~h}$, (b) $25 \%$ TFA heated at $110{ }^{\circ} \mathrm{C}$ for $4 \mathrm{~h}$, and (c) $25 \%$ TFA digested by microwave irradiation for $10 \mathrm{~min}$. "I" indicates peptides resulting from internal fragmentation. " $\mathrm{C}$ " and " $\mathrm{N}$ " indicate $\mathrm{C}$ - and N-terminal peptides, respectively.

illustrated ${ }^{\circ} \mathrm{in}^{\circ} \mathrm{acid}^{\circ} \mathrm{hydrolysis^{ \circ }} \mathrm{Of}^{\circ} \mathrm{BR}^{\circ}$ using $^{\circ} \mathrm{TFA} .{ }^{\circ}$ Figure $2 b^{\circ}$ shows $^{\circ}$ the ${ }^{\circ} \mathrm{MALDI}^{\circ}$ spectrum $^{\circ}$ of $^{\circ} \mathrm{BR}^{\circ}$ hydrolyzed $^{\circ}$ in $25 \%$ TFA by conventional heating at $110^{\circ} \mathrm{C}$ for $4 \mathrm{~h}$. Only one peptide peak from the N-terminus was observed. It was found that upon heating, BR aggregated, which might have prevented further hydrolysis. In contrast, when the same mixture of $25 \%$ TFA and BR was subjected to MAAH, no protein aggregates were observed after $10{ }^{9} \mathrm{~min}^{\circ}$ of microwave9irradiation. Figure $2 c^{\text {S }}$ shows the MALDI spectrum of the BR hydrolysate from MAAH. A number of peptide peaks with their masses assignable to BR fragments were observed with good signal-tonoise ratios. One plausible explanation for this striking difference between MAAH and acid hydrolysis with conventional heating is that microwave irradiation can assist in disrupting the protein aggregates in cases where proteins are merely suspended in an acid, preventing the solubilized proteins from aggregation, and denaturing and unfolding the proteins to expose both hydrophobic and hydrophilic residues to acid hydrolysis.

\section{Acid Type and Concentration}

To optimize the performance of MAAH, we examined several different acids at varying concentrations to hydrolyze BR. A proper acid for MAAH should not produce any interfering side reactions and should be easily removed by vacuum centrifugation. $\mathrm{HNO}_{3}$ and $\mathrm{H}_{2} \mathrm{SO}_{4}$ are oxidizing acids, so they were not chosen for the experiments. $\mathrm{H}_{3} \mathrm{PO}_{4}$ is not volatile and thus cannot be removed by vacuum centrifugation. Formic acid (shown above) and acetic acid (data not shown) were found to modify the N-terminus of peptides, so they were not studied further. In the end, $\mathrm{HCl}$ and TFA were selected for in-depth studies to determine their suitability for MAAH.

It was found that acid type, acid concentration, and microwave irradiation time all affect the number and type of peptides produced from MAAH of BR. Low acid concentration (e.g., $0.1 \mathrm{M} \mathrm{HCl}$ or $0.3 \mathrm{M} \mathrm{TFA}$ ) and short irradiation time (e.g., $2 \mathrm{~min}$ ) resulted in fragments containing the C- and/or N-terminus. On increasing acid concentration and irradiation time, more internal fragment ions were observed, along with the C- and $\mathrm{N}$-terminal fragment ions. At a higher concentration (e.g., $1.5 \mathrm{M} \mathrm{HCl}$ or TFA) and a longer irradiation time (e.g., $10 \mathrm{~min}$ ), $\mathrm{HCl}$ resulted in more nonspecific cleavages (see next section). In addition, 1.5 M TFA gave a better signal-to-noise ratio than that obtained with $1.5 \mathrm{M} \mathrm{HCl}$. From these results, we concluded that TFA was a better choice for generating relatively more specific internal cleavage products and producing optimal lengths of peptides for tandem MS analysis. We then carried out a detailed optimization of acid concentration and digestion time studies for TFA. It was found that $3 \mathrm{M}$ TFA $(25 \% \mathrm{vol} / \mathrm{vol})$ digestion for $10 \mathrm{~min}$ gave the optimal results in terms of the number of peptides generated and sequence information covered for BR.

It is worth noting that some of the observations found during the acid optimization experiments seem to suggest that protein denaturation may play an important role in hydrolysis. Protein denaturation is likely facilitated by heating resulting from microwave irradiation while hydrolysis of polypeptide bonds takes place. For example, $0.3 \mathrm{M}$ TFA digestion for $2 \mathrm{~min}$ did not yield any signal while $1.5 \mathrm{M}$ TFA digestion for the same irradiation time yielded peptides from both the Cand $\mathrm{N}$-terminus. However, $0.3 \mathrm{M} \mathrm{HCl}$ digestion for 2 min of irradiation yielded peptides from the C-terminus, while $1.5 \mathrm{M} \mathrm{HCl}$ digestion for the same irradiation time yielded peptides from both the $\mathrm{C}$ - and $\mathrm{N}$ - terminus as well as peptides resulting from internal fragmentation. These observations can be attributed to 0.3 M TFA and heating for $2 \mathrm{~min}$ irradiation being insufficient to denature the protein. So membrane proteins under these "mild" conditions were not exposed to the cleavage of polypeptide bonds. Increasing acid concentration or increasing irradiation time yielded hydrolytic peptides from $\mathrm{N}$ - and $\mathrm{C}$-terminus. Further increases in acid concentration or irradiation time not only generated 
hydrolytic peptides from the C- and N-terminus but also yielded hydrolytic peptides from internal fragmentations.

\section{Acid Cleavage Specificity}

We found that in using TFA for MAAH there was acid-cleavage specificity to produce the peptides. This is consistent ${ }^{\circ}$ with $^{\circ}$ those ${ }^{\circ}$ reported $^{\circ}$ by $^{\circ}$ Gobom $^{\circ}$ et $^{\circ}$ al. $^{\circ}[20]$ using direct MALDI analysis of proteins digested by acid vapors. In our experiment, BR was digested by $25 \%$ TFA with microwave irradiation for $10 \mathrm{~min}$. To examine the acid-cleavage specificity and whether the very hydrophobic domains of a membrane protein could be cleaved by the acid, the hydrolysate of BR was separated by $\mathrm{C} 18$ reversed-phase chromatography, followed by direct deposition of the fractions to the MALDI target. MALDI MS and MS/MS spectra of peptides on each fraction were then obtained and the peptides were identified ${ }^{\circ}$ by $^{\circ} \mathrm{MS} \mathrm{MS}^{\circ}$ database ${ }^{\circ}$ searching..$^{\circ}$ Figure $^{\circ} 3$ shows some of the representative MALDI MS spectra.

One interesting finding from the BR acid hydrolysis
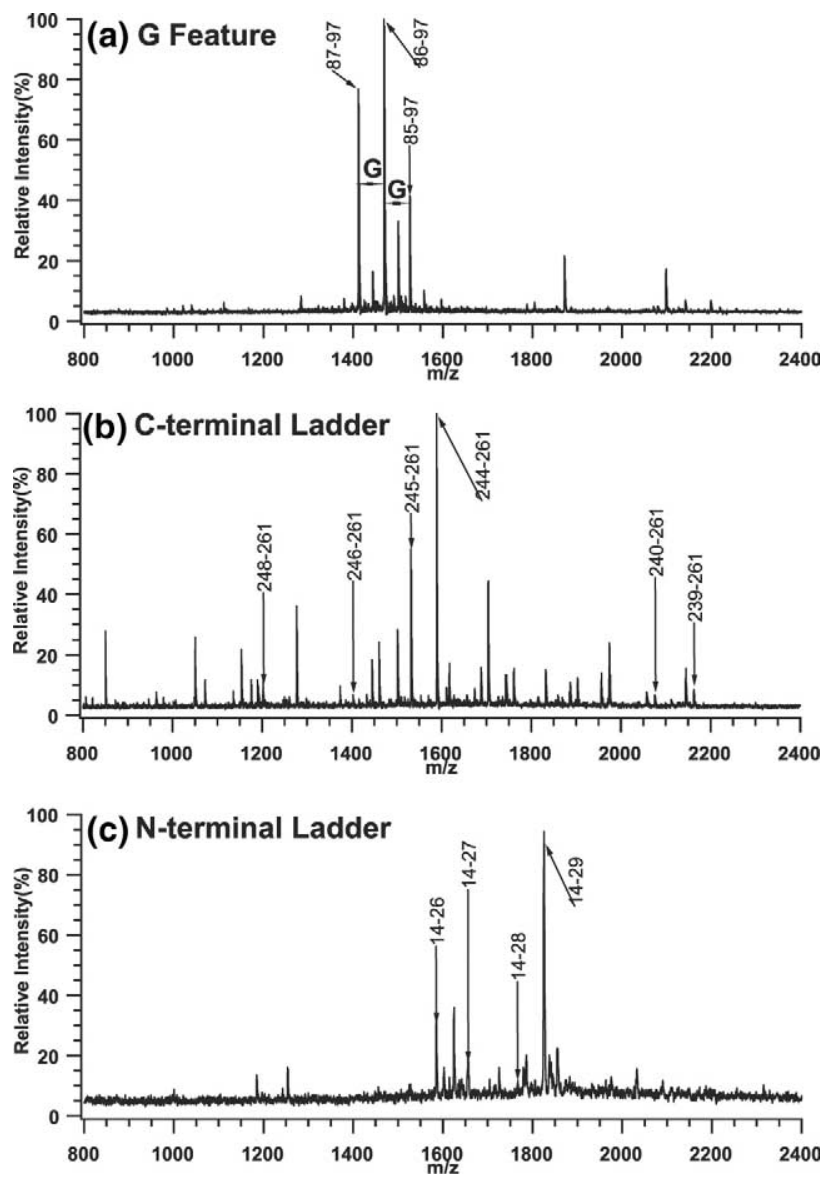

Figure 3. MALDI MS spectra of LC fractionated bacteriorhodopsin peptides: (a) Fraction 34, (b) fraction 25, and (c) fraction 64. A reversed-phase HPLC separation was done by injecting $5 \mu \mathrm{g}$ of the bacteriorhodopsin hydrolysate. The peptides were directly fractionated to a MALDI plate using a heated droplet LC-MALDI interface. experiment is the readiness of the cleavage on both sides of glycine using $25 \%$ TFA for digestion. TFA is an ion-pairing reagent commonly used as a modifier for HPLC separation of peptides and proteins. It is likely that the extent of the formation of TFA/protein complex plays some role in hydrolysis. Glycine has the least steric effect on TFA/proton attachment to the peptide bond which is presumed to initiate and catalyze the hydrolysis process. In the MALDI MS spectra, peptide pairs with 57 Da mass differences produced by the cleavage on both sides of glycine are always abundant. Even ${ }^{\circ}$ after ${ }^{\circ} \mathrm{HPLC}{ }^{\circ}$ separation, ${ }^{\circ}{ }^{\circ}{ }^{\circ}$ hhown $^{\circ}{ }^{\circ}{ }^{\circ}$ Figure $^{\circ} 3 a^{\circ}{ }^{\circ}{ }^{\circ}$ an example, pairs of peptides are still observed in the same fraction, suggesting peptides with and without a terminal glycine have similar chromatographic retentions.

This glycine cleavage specificity can be used to aid in protein identification. This can be illustrated using the MALDIMS ${ }^{\circ}$ spectrum ${ }^{\circ}$ of ${ }^{\circ}$ raction $34^{\circ}$ shown in ${ }^{\circ}$ Figure $3 a$. The monoisotopic mass of the peak labeled as 85-97 is 1525.66 Da. For peptide mass mapping, this peak matches six peptides from BR with $200 \mathrm{ppm}$ error tolerance: AVEGVSQAQITGRPE (8-22; $1525.69 \mathrm{Da})$, GVSQAQITGRPEWI (11-24; $1525.73 \mathrm{Da})$, GGEQNPIYWARYA (85-97; 1525.66 Da), LLLLDLALLVDADQ (105-118; $1525.82 \mathrm{Da})$, VWWAISTAAMLYI (149-161; $1525.85 \mathrm{Da})$, and VWLIGSEGAGIVPLN (201-215; $1525.78 \mathrm{Da})$. However, the two adjacent peaks have a mass difference of $57 \mathrm{Da}$, which indicates the presence of two adjacent glycines. Therefore, the sequence for the peptide with a mass of 1525.66 Da should be GGEQNPIYWARYA (85-97); the sequence for the adjacent peak with a mass of 1468.78 Da should be GEQNPIYWARYA (86-97); and the sequence for the peptide with a mass of 1411.72 Da should be EQNPIYWARYA (87-97). Subsequent MALDI-MS/MS experiments have confirmed the results (data not shown). For an unknown sample, co-elution of the peptide pair can be very useful for protein identification and confirmation of the database search results.

MAAH can also produce useful information in the form of sequence ladders generated from the $\mathrm{C}$ - or $\mathrm{N}$-terminus that not only provide peptide masses but also give some sequence information. For BR, peptide ladders could be observed in some fractions. For example, $^{\circ}$ Figure $^{\circ} 3 b^{\circ}$ shows $^{\circ}$ the ${ }^{\circ} \mathrm{MALDI}^{\circ} \mathrm{MS}^{\circ}$ spectrum ${ }^{\circ}$ of fraction 25. C-terminal fragmentation is observed in this spectrum and is labeled as 248-261, 246-261, 245-261, $244-261,{ }^{\circ} 240-261{ }^{\circ}$ and $^{\circ} 239-261 .^{\circ}$ Figure $^{\circ} 3 c^{\circ}$ shows $^{\circ}$ the MALDI MS spectrum of fraction 64. N-terminal fragmentation is observed in this spectrum and is labeled as 14-26, 14-27, 14-28, and 14-29.

MALDI MS/MS analysis of the LC fractionated peptides from the BR hydrolysate, combined with database searching, reveals effective coverage of both hydrophilic ${ }^{\circ}$ and ${ }^{\circ}$ hydrophobic ${ }^{\circ}$ parts $^{\circ}{ }^{\circ} f^{\circ}$ the ${ }^{\circ}$ protein. ${ }^{\circ}$ Figure $^{\circ} 4^{\circ}$ shows $^{\circ}$ the ${ }^{\circ} \mathrm{MALDI}^{\circ} \mathrm{MS} / \mathrm{MS}^{\circ}$ spectra $^{\circ}$ of $^{\circ}$ two $^{\circ}$ peptides from the most hydrophobic transmembrane domains of BR. The underlined sequences indicate the amino acid residues inside the membrane. The MS/MS 

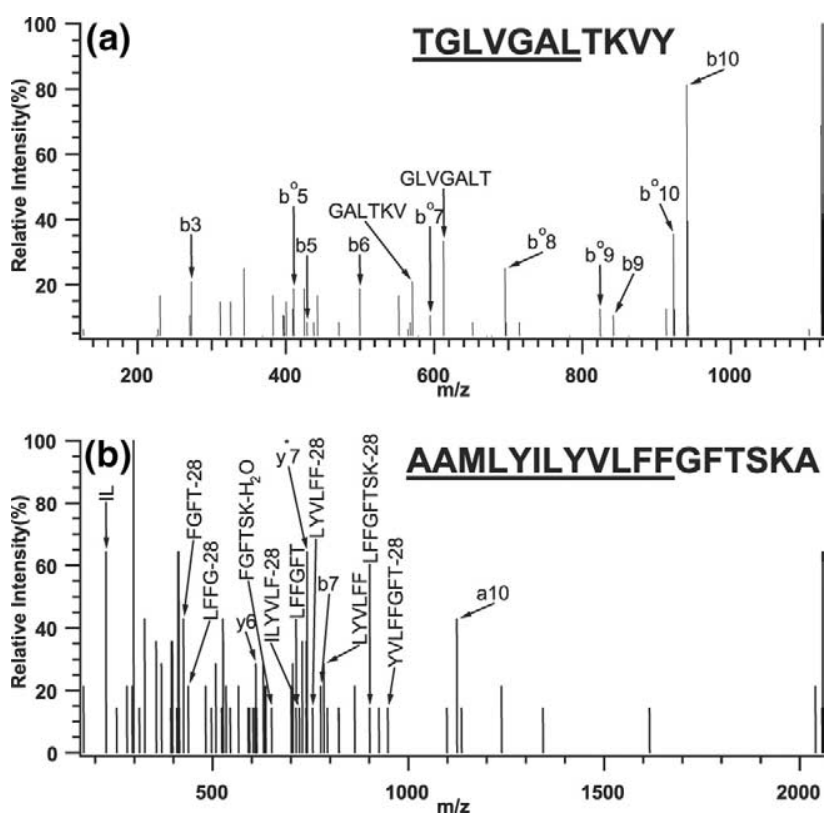

Figure 4. MALDI MS/MS spectra of peptides from the most hydrophobic transmembrane domains of bacteriorhodopsin: (a) A peptide from transmembrane domain D with a GRAVY value of 1.910, and (b) a peptide from transmembrane domain $\mathrm{E}$ with a GRAVY value of 1.930. Domain sequence and designation are shown ${ }^{\circ}{ }^{\circ}$ Figure $^{\circ} 5$.

spectra of the peptides covering all seven transmembrane domains along with a table listing all the peptides detected from this LC-MALDI experiment are available by contacting the corresponding author by email: liang.li@ualberta.ca. ${ }^{\circ}$ Figure $^{\circ} 5^{\circ}$ shows $^{\circ}$ the ${ }^{\circ} \mathrm{BR}^{\circ}$ sequence

Signal Peptide Cleaved

(A)

MLELLPTAVEGVSQAQITGRPEW IWLALGTALMG (A) (B)

LGTLYFLVKGMGVSDPDAKKFY AITTLVPAIAFTM (B) (C) YLSMLDGYGLTMVPFGGEQNPIYWARYADWLFT (C) (D) PLLLLDLALLVDADQG ILALVGADGIMIGTGLVG (D)

ADTKVYSYR FVWWAI S1 AAMLYILYVLFFGFTSKA ESMRPEVASTFK VLRNVTVVLWSAYPVVWLIGSEG AGIVPLNIETLLFMVI DASAKVGFGLI] LRSRAIFG

Figure 5. Sequence coverage of bacteriorhodopsin peptides generated using $25 \%$ TFA and $10 \mathrm{~min}$ microwave digestion and detected by LC-MALDI MS and MS/MS. $5 \mu \mathrm{g}$ of the bacteriorhodopsin hydrolysate was injected for LC-MALDI. Double-line rectangles indicate the seven transmembrane domains and underlinings indicate the peptides identified by MALDI MS/MS and MASCOT search. Three circled amino acid residues were not covered by the peptides detected. and summarizes the sequence coverage from peptides detected ${ }^{\circ}$ by $^{\circ}$ this ${ }^{\circ}$ method. ${ }^{\circ}$ As ${ }^{\circ}$ Figure $^{\circ} 5^{\circ}$ shows, ${ }^{\circ}$ the ${ }^{\circ}$ peptides detected cover the entire sequence except for three internal amino acids.

The ability to generate high sequence coverage using MAAH can be very useful for determining posttranslational modification (PTM) of a protein. Many proteins experience PTMs, such as peptide cleavage from the Cor N-terminus. This method yields peptide ladders from the $\mathrm{C}$ - and $\mathrm{N}$-terminus and helps determine whether this type of PTM has occurred. In the case of $\mathrm{BR}$, signal peptide cleavage from the $\mathrm{N}$-terminus (see Figure $\left.^{\circ} 3 \mathrm{c}\right)^{\circ}$ and $^{\circ}$ final $^{\circ}$ cleavage $^{\circ}$ of ${ }^{\circ} \mathrm{C}$-terminal ${ }^{\circ} \mathrm{D}^{\circ}$ (see Figure $\left.^{\circ} 6 a\right)^{\circ}$ were $^{\circ}$ observed..$^{\circ} \operatorname{In}^{\circ}$ the $^{\circ}$ spectrum ${ }^{\circ}$ shown $^{\circ}$ in Figure $^{\circ} 6 \mathrm{~b},{ }^{\circ} \mathrm{N}$-terminal ${ }^{\circ}$ transformation ${ }^{\circ}$ of $^{\circ}$ glutamine ${ }^{\circ}$ to pyroglutamic acid was also found for this protein.

\section{Detection Sensitivity}

As we have demonstrated, the MAAH method can provide more cleavage sites, resulting in extensive sequence coverage. On the other hand, multiple cleavages on a protein can potentially result in many peptides that may complicate the downstream analysis by LC-MS. However, reducing the protein concentration decreases significantly the number of peptides detected by MALDI MS. As illustrated ${ }^{\circ}{ }^{\circ}$ Figure $\%$, ${ }^{\circ}$ different ${ }^{\circ}$ concentrations ${ }^{\circ}$ of ${ }^{\circ} \mathrm{BR}^{\circ}$ were hydrolyzed by $25 \%$ TFA with microwave irradiation for $10 \mathrm{~min}$. As the BR concentration was decreased from 100 $\mathrm{ng} / \mu \mathrm{l}$ to $1 \mathrm{ng} / \mu \mathrm{l}$, the signal-to-noise ratio and the number of peptide peaks decreased. Interestingly, the terminal

(a) SRAIFGEAEAPEPSAGDGAAATS(D)

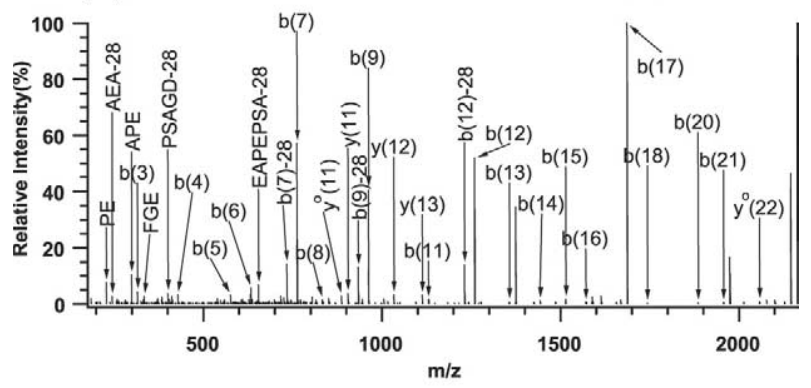

(b) QAQITGRPEWIWLALG

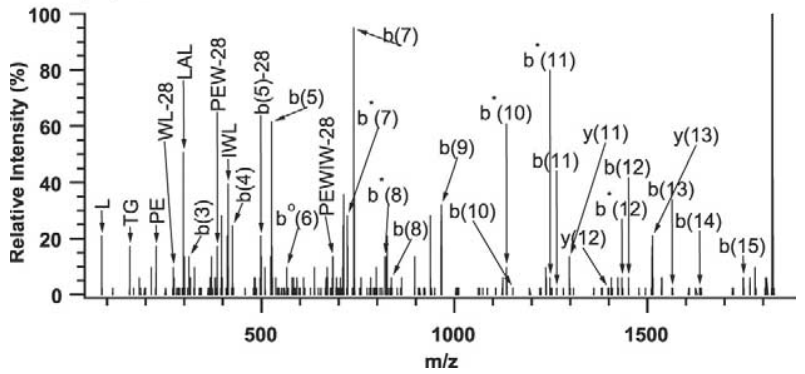

Figure 6. MALDI MS/MS spectra of bacteriorhodopsin peptides containing posttranslational modifications: (a) A peptide showing cleavage of C-terminal aspartic acid, and (b) a peptide showing $\mathrm{N}$-terminal transformation of glutamine to pyroglutamic acid. 

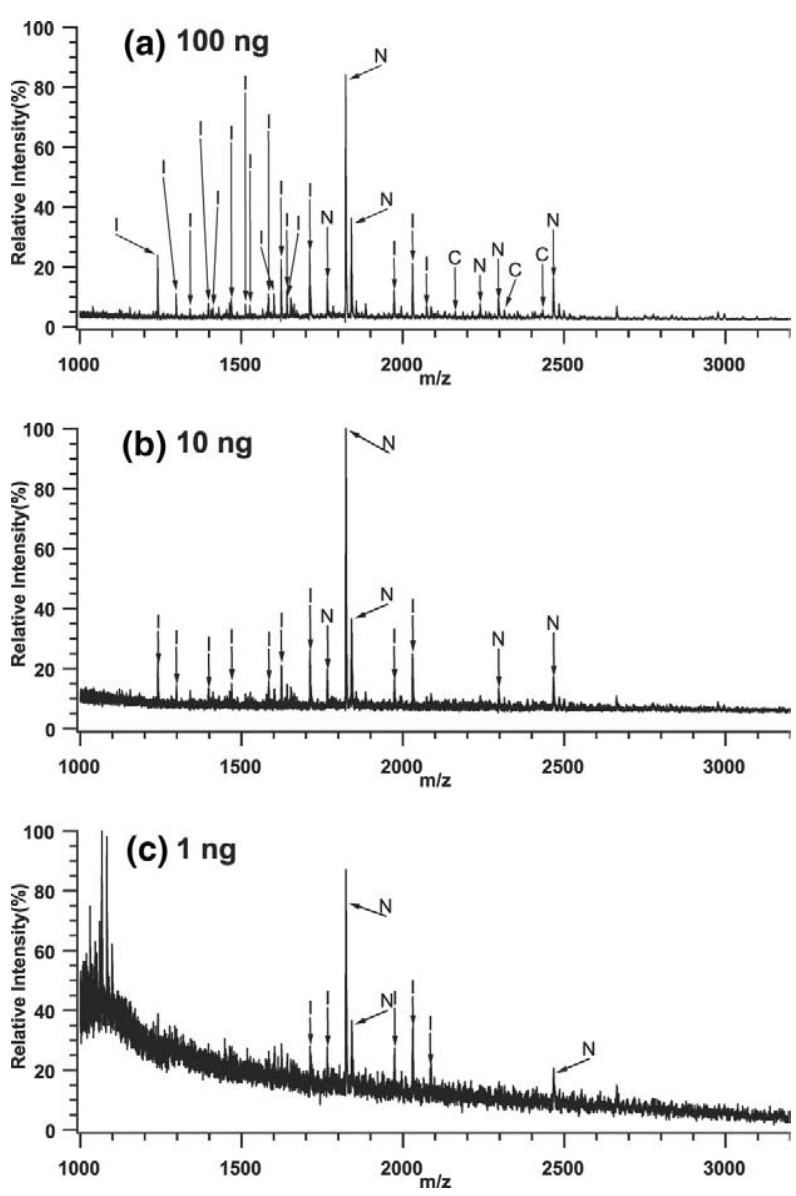

Figure 7. MALDI MS spectra of hydrolysates generated from different concentrations of bacteriorhodopsin: (a) $100 \mathrm{ng} / \mu \mathrm{l}$, (b) 10 $\mathrm{ng} / \mu \mathrm{l}$, and (c) $1 \mathrm{ng} / \mu \mathrm{l}$. In each case, $10 \mu \mathrm{l}$ of protein solution in $25 \%$ TFA was subjected to microwave irradiation for $10 \mathrm{~min}$. The hydrolysate was then dried by Speedvac and redissolved in $5 \mu \mathrm{l}$ of the second-layer HCCA matrix solution. $0.5 \mu \mathrm{l}$ of the matrix/ analyte solution was deposited to the first layer for MALDI analysis.

sequence ladders can still be observed in the lowest concentration spectrum, while a number of peptides from internal fragmentation disappear. The results shown in Figure $^{\circ} 7^{\circ}$ demonstrate $^{\circ}$ that $^{\circ}$ the $^{\circ} \mathrm{MAAH}^{\circ}$ method $^{\circ}$ can $^{\circ}$ still generate several peptides from a protein concentration of down to $1 \mathrm{ng} / \mu \mathrm{l}$. Unlike enzyme digestion, where ion suppression from protease autolysis peptides can occur when a low concentration of proteins is used for digestion, MAAH does not introduce background peaks, as shown

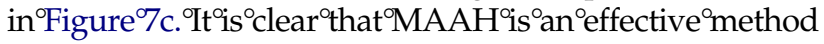
for digesting low concentrations of proteins and the spectra generated consist of a few peaks that should be readily handled by conventional LC separation strategies, such as 1D- or 2D-LC methods.

\section{Analysis of a Membrane Protein Enriched Cell Fraction}

This MAAH method was applied to identify membrane proteins isolated from human breast cancer cell line
MCF7. The heated droplet LC-MALDI interface reported previously was used for on-line peptide fractionation ${ }^{\circ}[36] .{ }^{\circ}$ The $^{\circ}$ fractions ${ }^{\circ}$ were $^{\circ}$ directly $^{\circ}$ collected $^{\circ}$ into $^{\circ}$ a 100-well ${ }^{\circ} \mathrm{MALDI}^{\circ}$ plate $^{\circ}$ Figure $^{\circ} 8 \mathrm{a}^{\circ}$ shows $^{\circ}$ the ${ }^{\circ} \mathrm{UV}^{\circ} \mathrm{Chro}$ matogram from the $\mathrm{C} 18$ column separation of the MAAH hydrolysate. No late eluting peaks (i.e., retention time $>50 \mathrm{~min}$ ) are observed, indicating that most proteins, ${ }^{\circ}$ if ${ }^{\circ}$ not $^{\circ}$ all, ${ }^{\circ}$ were ${ }^{\circ}$ hydrolyzed. ${ }^{\circ}$ Figure $^{\circ} 8 \mathrm{~b}^{\circ}$ and ${ }^{\circ} \mathrm{C}$ show the MALDI MS spectra of two fractions. The MS/MS spectra of two peptides from the transmembrane domains of an integral membrane protein ATP carrier $^{\circ}\left(\mathrm{P}^{2} 5141\right)^{\circ}$ are $^{\circ}$ shown $^{\circ}$ in $^{\circ}$ Figure $^{\circ} 8 \mathrm{~d}^{\circ}$ and $^{\circ} \mathrm{e}^{\circ}$ The $^{\circ}$ underlined sequences indicate the amino acids residing inside the transmembrane domains. For this apparently high abundance protein, a total of 11 peptides were detected, providing sequence coverage of $24 \%$, including 10 peptides containing parts of the transmembrane domains.

Using MALDI MS/MS with 1D-LC separation, a total of 119 proteins with GRAVY scores ranging from -1.135 to 0.992 were identified by MS/MS database searching based on matches of at least two peptides to a protein. Among them, 41 proteins are membrane proteins. As we described earlier, sequence ladders containing the $\mathrm{N}$ - or C-terminus of BR are present in the spectrum even from the hydrolysate generated using a small amount of protein. In the analysis of this real complex mixture, many proteins were identified from terminal peptides (the peptide sequences used to identify each protein are available by contacting the corresponding author by email: liang.li@ualberta.ca). For example, two peptides identified for the soluble protein P19338 were from its C-terminus, i.e., DHKPQGKKTKFE and GGDHKPQGKKTKFE. Three peptides identified for integral membrane protein Q9NZ01 were from its C-terminus, i.e., PPLRMPIIPFLL, PLRMPIIPFLL, and RMPIIPFLL. The sequence ladders provided additional information to confirm the protein identification results, and distinguish similar sequences from different proteins generated by database searching. For example, in the list of the proteins identified, there are three ATP carrier protein isoforms with differences in the C-terminal amino acid. Sequence ladders from the Cterminus clearly show the terminal amino acid difference, allowing the differentiation of these isoforms: the fibroblast isoform having $\mathrm{T}$ as the C-terminus, the $\mathrm{T} 1$ isoform having $\mathrm{V}$ as the $\mathrm{C}$-terminus, and the $\mathrm{T} 2$ isoform having $\mathrm{I}$ as the $\mathrm{C}$-terminus.

The above example illustrates that, even with only one-dimensional HPLC separation of the hydrolysate, we can already identify a number of membrane proteins from the MCF7 membrane-enriched fraction. This method is very simple and quick; we merely suspend the acetone-precipitated sample in 25\% TFA, followed by microwave irradiation for $10 \mathrm{~min}$. The hydrolysate can be injected directly into HPLC for MS and MS/MS analysis. While LC-MALDI is used for this work, the hydrolysate can also be analyzed by ESI LC/MS (data not shown). 


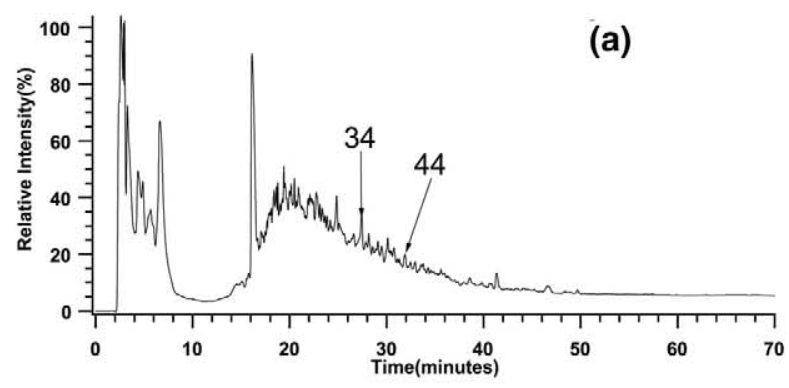

(b)

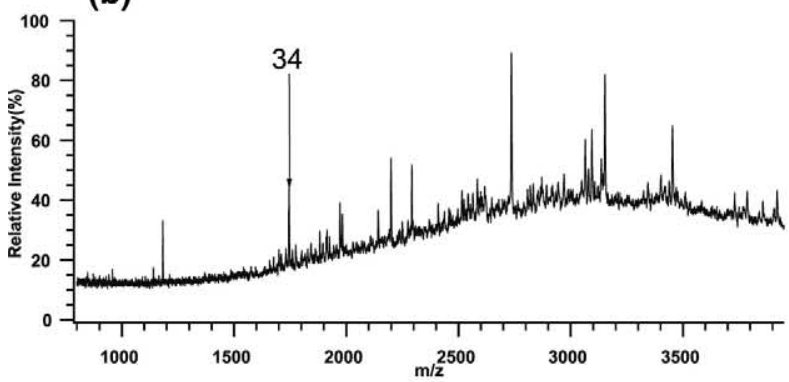

(c)

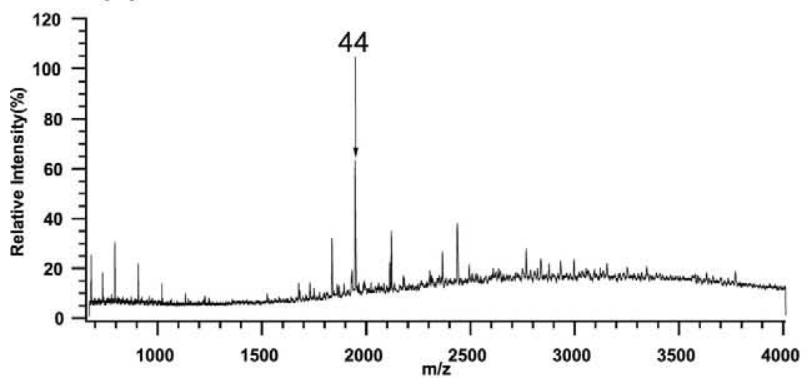

(d)

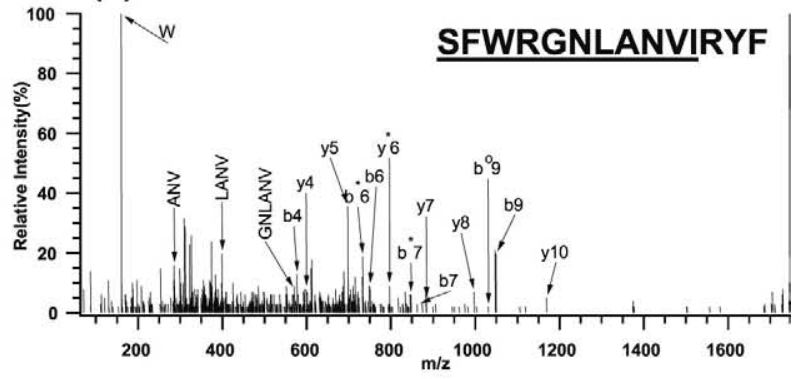

(e)

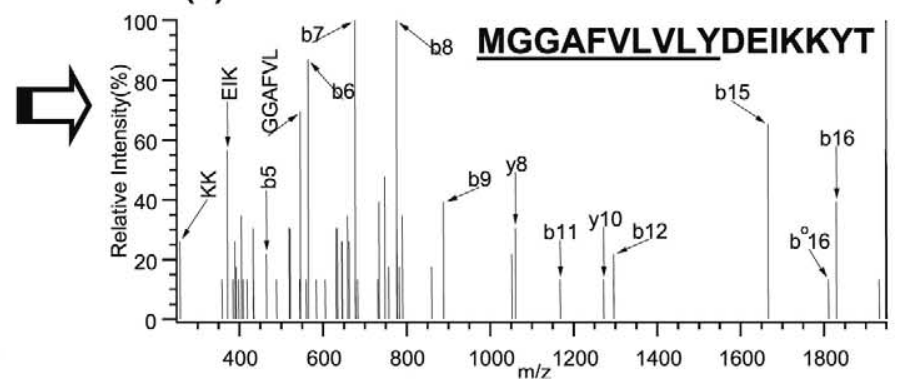

Figure 8. (a) UV chromatogram from a reserved-phase HPLC separation of the hydrolysate generated from microwave-assisted acid hydrolysis of a membrane protein enriched fraction from human breast cell line MCF7. About $50 \mu \mathrm{g}$ of the protein hydrolysate was injected. MALDI MS spectra of (b) fraction 34 and (c) fraction 44. MS/MS spectra of (d) a peptide from fraction 34 (GRAVY 0.400) and (e) a peptide from fraction 44 (GRAVY 1.037). These two product ion spectra were matched with the peptide sequences corresponding to parts of the transmembrane domains of the integral membrane protein ATP carrier (P05141) fractionated from human breast cancer cell line MCF7.

\section{Conclusions}

We have described a method of using microwaveassisted acid hydrolysis to degrade proteins into peptides for MS characterization. It works for membrane proteins merely suspended in 25\% TFA aqueous solution and does not require the use of strong surfactants to solubilize proteins. The presented method expands the range of proteins that can be quickly analyzed by MS and circumvents the reliance on specific proteases. It improves throughput by reducing the time required for protein digestion. This method also offers good sequence coverage including transmembrane domains. The unique cleavage specificity such as $\mathrm{C}$ - or $\mathrm{N}$-terminal fragmentation and the feature of glycine cleavage provides useful information for positive protein identification.

Compared to enzymatic digestion, this MAAH method is fast and detergent-free. It involves a simple sample handling process and there are no background peptides, such as those from protease autolysis in enzyme digestion, introduced in MAAH. This method also provides some advantages over other acid hydrolysis techniques. Protein aggregates, which prevent degradation, are observed in acid hydrolysis of membrane proteins with conventional heating. Under microwave irradiation, not only faster degradation can be obtained, but also efficient cleavage in transmembrane domains can be achieved, resulting in more sequence coverage.

\section{Acknowledgment}

This work was funded by the Natural Sciences and Engineering Research Council of Canada (NSERC). 


\section{References}

1. Wu, C. C.; Yates J. R. III. The Application of Mass Spectrometry to Membrane Proteomics. Nat. Biotechnol 2003, 21, 262-267.

2. Rabilloud, T. Membrane Proteins Ride Shotgun. Nat. Biotechnol. 2003, 21, 508-510.

3. Han, D. K.; Eng, J.; Zhou, H.; Aebersold, R. Quantitative Profiling of Differentiation-induced Microsomal Proteins Using Isotope-Coded Affinity Tags and Mass Spectrometry. Nat. Biotechnol. 2001, 19, 946-951.

4. Norris, J. L.; Porter, N. A.; Caprioli, R. M. Mass Spectrometry of Intracellular and Membrane Proteins Using Cleavable Detergents. Anal. Chem. 2003, 75, 6642-6647.

5. Blonder, J.; Goshe, M. B.; Moore, R. J.; Pasa-Tolic, L.; Masselon, C. D.; Lipton, M. S.; Smith, R. D. Enrichment of Integral Membrane Proteins for Proteomic Analysis Using Liquid Chromatography-Tandem Mass Spectrometry. J. Prot. Res. 2002, 1, 351-360.

6. Goshe, M. B.; Blonder, J.; Smith, R. D. Affinity Labeling of Highly Hydrophobic Integral Membrane Proteins for Proteome-Wide Analysis. J. Prot. Res. 2003, 2, 153-161.

7. Blonder, J.; Conrads, T. P.; Yu, L.; Terunuma, A.; Janini, G. M.; Issaq, H. J.; Vogel, J. C.; Veenstra, T. D. A Detergent- and Cyanogen Bromide-Free Method for Integral Membrane Proteomics: Application to Halobacterium Purple Membranes and the Human Epidermal Membrane Proteome. Proteomics 2004, 4, 31-45.

8. Ball, L. E.; Oatis, J. E.; Dharmasiri, K.; Busman, M.; Wang, J.; Cowden, L. B.; Galijatovic, A.; Chen, L.; Crouch, R. K.; Knapp, D. R. Mass Spectrometric Analysis of Integral Membrane Proteins: Application to Complete Mapping of Bacteriorhodopsins and Rhodopsin. Prot. Sci. 1998, 7, 758-764.

9. Ablonczy, Z.; Kono, M.; Crouch, R. K.; Knapp, D. R. Mass Spectrometric Analysis of Integral Membrane Proteins at the Subnanomolar Level: Application to Recombinant Photopigments. Anal. Chem. 2001, 73, 4774-4779.

10. Washburn, M. P.; Wolters, D.; Yates, J. R. III. Large-Scale Analysis of the Yeast Proteome by Multidimensional Protein Identification Technology. Nat. Biotechnol. 2001, 19, 242-247.

11. Quach, T. T. T.; Li, N.; Richard, D. P.; Zheng, J.; Keller, B. O.; $\mathrm{Li}$, L. Development and Applications of In-Gel CNBr/Tryptic Digestion Combined with Mass Spectrometry for the Analysis of Membrane Proteins. J. Prot. Res. 2003, 2, 543-552.

12. Wu, C. C.; MacCoss, M. J.; Howell, K. E.; Yates, J. R. III. A Method for the Comprehensive Proteomic Analysis of Membrane Proteins. Nat. Biotechnol. 2003, 21, 532-538.

13. Sanger, F.; Thompson, E.O.P. The Amino-acid Sequence in the Glycyl Chain of Insulin: 1. The Identification of Lower Peptides from Partial Hydrolysates. Biochem. J. 1953, 53, 353-366.

14. Sonderegger, P. R.; Jaussi, H.; Gehring, K.; Brunschweiler, K.; Christen, P. Peptide Mapping of Protein Bands from Polyacrylamide Gel Electrophoresis by Chemical Cleavage in Gel Pieces and Re-electrophoresis. Anal. Biochem. 1982, 122, $298-$ 301.

15. Vanfleteren, J. R.; Raymackers, J. G.; van Bun, S. M.; Meheus, L. A. Peptide Mapping and Microsequencing of Proteins Separated by SDS-PAGE after Limited In Site Acid Hydrolysis. BioTechnique 1992, 12, 550-557.

16. Tsugita, A.; Takamoto, K.; Kamo, M.; Iwadate, H. C-terminal Sequencing of Protein. A Novel Partial Acid Hydrolysis and Analysis by Mass Spectrometry. Eur. J. Biochem. 1992, 206, 691-696

17. Tsugita, A.; Kamo, M.; Miyazaki, K.; Takayama, M.; Kawakami, T.; Shen, R.; Nozawa, T. Additional Possible Tools for Identification of Proteins on One- or Two-Dimensional Electrophoresis. Electrophoresis 1998, 19, 928-938.

18. Vorm, O.; Roepstorff, P. Peptide Sequence Information Derived by Partial Acid Hydrolysis and Matrix-Assisted Laser
Desportion/Ionization Mass Spectrometry. Biol. Mass Spectrom. 1994, 23, 734-740.

19. Zubarev, R. A.; Chivanov, V. D.; Hakansson, P.; Sundkvist, B. U. R. Peptide Sequencing by Partial Acid Hydrolysis and High Resolution Plasma Desorption Mass Spectrometry. Rapid Commun. Mass Spectrom. 1994, 8, 906-912.

20. Gobom, J.; Mirgorodskaya, E.; Nordhoff, E.; Hojrup, P.; Roepstorff, P. Use of Vapor-Phase Acid Hydrolysis for Mass Spectrometric Peptide Mapping and Protein Identification. Anal. Chem. 1999, 71, 919-927.

21. Li, A.; Sowder, R. C., II; Henderson, L. E.; Moore, S. P.; Garfinfel, D. J.; Fisher, R. J. Chemical Cleavage at Aspartyl Residues for Protein Identification. Anal. Chem. 2001, 73, 5395-5402.

22. Shevchenko, A.; Loboda, A.; Shevchenko, A.; Ens, W.; Standing, K. G. MALDI Quadrupole Time-of-Flight Mass Spectrometry: A Powerful Tool for Proteomic Research. Anal. Chem. 2000, 72, 2132-2141.

23. Lin, S. H.; Tornatore, P.; Weinberger, S. R.; King, D.; Orlando, R. Limited Acid Hydrolysis as a Means of Fragmenting Proteins Isolated upon Proteinchip Array Surfaces. Eur. J. Mass Spectrom. 2001, 7, 131-141.

24. Ocana, M. F.; Neubert, H.; Przyborowska, A.; Parker, R.; Bramley, P.; Halket, J.; Patel, R. BSE Control: Detection of Gelatine-Derived Peptides in Animal Feed by Mass Spectrometry. Analyst 2004, 129, 111-115.

25. Giguerre, R. J.; Bray, T. L.; Duncan, S. M. Application of Commercial Microwave Ovens to Organic Synthesis. Tetrahedron Lett. 1986, 27, 4945-4948.

26. Gedye, R.; Smith, F.; Westway, K.; Ali, H.; Baldisera, L.; Laberge, L.; Rousell, J. The Use of Microwave Ovens for Rapid Organic Synthesis. Tetrahedron Lett. 1986, 27, 279-282.

27. Kingston, H. M.; Haswell, S. J. Microwave-Enhanced Chemistry: Fundamentals, Sample Preparation, and Applications; ACS: Washington, D.C., 1997.

28. Lew, A.; Krutzik, P. O.; Hart, M. E.; Chamberlin, A. R. Increasing Rates of Reaction: Microwave-Assisted Organic Synthesis for Combinatorial Chemistry. J. Comb. Chem. 2002, 4, 95-105.

29. Chen, S. T.; Chiou, S. H.; Chu, Y. H.; Wang, K. T. Rapid Hydrolysis of Proteins and Peptides by Means of Microwave Technology and Its Application to Amino Acid Analysis. Int. J. Peptide Protein Res. 1987, 30, 572-576.

30. Chiou, S. H.; Wang, K. T. Peptide and Protein Hydrolysis by Microwave Irradiation. J. Chromatogr. 1989, 491, 424-431.

31. Chen, S. T.; Chiou, S. H.; Wang, K. T. Enhancement of Chemical Reactions by Microwave Irradiation. J. Chin. Chem. Soc. 1991, 38, 85-91.

32. Chen, S. T.Tseng, P. H.; Yu, H. M.; Wu, C. Y.; Hsiao, K. F.; Wu, S. H.; Wang, K. T. The Studies of Microwave Effects on the Chemical Reactions. J. Chin. Chem. Soc. 1997, 44, 169-182.

33. Bose, A. K.; Ing, Y. H.; Lavlinskaia, N.; Sareen, C.; Pramanik, B. N.; Bartner, P. L.; Liu, Y. H.; Heimark, L. Microwave Enhanced Akabori Reaction for Peptide Analysis. J. Am. Soc. Mass Spectrom. 2002, 13, 839-850.

34. Pramanik, B. N.; Ing, Y. H.; Bose, A. K.; Zhang, L. K.; Liu, Y. H.; Ganguly, S. N.; Bartner, P. Rapid Cyclopeptide Analysis by Microwave Enhanced Akabori Reaction. Tetrahedron Lett. 2003, 44, 2565-2568.

35. Pramanik, B. N.; Mirza, U. A.; Ing, Y. H.; Liu, Y. H.; Bartner, P. L.; Weber, P. C.; Bose, A. K. Microwave-Enhanced Enzyme Reaction for Protein Mapping by Mass Spectrometry: A New Approach to Protein Digestion in Minutes. Prot. Sci. 2002, 11, 2676-2687.

36. Zhang, B.; McDonald, C.; Li, L. Combining Liquid Chromatography with MALDI Mass Spectrometry Using a Heated Droplet Interface. Anal. Chem. 2004, 76, 992-1001. 
37. Dai, Y. Q.; Whittal, R. M.; Li, L. Two-Layer Sample Preparation: A Method for MALDI-MS Analysis of Complex Peptide and Protein Mixtures. Anal. Chem. 1999, 71, 1087-1091.

38. Hixson, K. K., Rodriguez, N., Camp, D. G. II, Lipton, M. S., Smith, R. D. Evaluation of Enzymatic Digestion and Liquid
Chromatography-Mass Spectrometry Peptide Mapping of the Integral Membrane Protein Bacteriorhodopsin. Electrophoresis 2002, 23, 3224-3232.

39. Smith, B. J. In The Protein Protocols Handbook, 2nd ed.; Walker, J. M.; Ed Humana Press: Totowa, NJ, 2002; pp 485-491. 